\title{
PENCAPAIAN AKADEMIK MURID LELAKI DAN PEREMPUAN: PERANAN SOKONGAN PEMBELAJARAN DAN KETERLIBATAN MURID
}

\section{ACADEMIC ACHIEVEMENT AMONG MALE AND FEMALE STUDENTS: THE ROLE OF LEARNING SUPPORT AND STUDENTS' ENGAGEMENT}

\author{
${ }^{1}$ Hanita Mohd Yusoff \& ${ }^{2}$ Norzaini Azman \\ ${ }^{1,2}$ Fakulti Pendidikan, \\ Universiti Kebangsaan Malaysia
}

${ }^{2}$ Corresponding author: norzai12@ukm.edu.my

Received: 15 November 2017 Revised: 5 November 2018 Accepted: 21 November 2018

\section{ABSTRAK}

Tujuan - Kajian ini bertujuan untuk meneliti hubungan keterlibatan murid, sokongan pembelajaran dan pencapaian akademik mengikut gender.Ia juga meneliti samaada terdapat peranan keterlibatan sebagai perantara bagi hubungan antara faktor sokongan pembelajaran dan pencapaian murid.

Metodologi - Tinjauan keratan rentas digunakan untuk mengumpul data yang melibatkan keterlibatan murid di sekolah, sokongan pembelajaran dan pencapaian akademik. Sampel kajian adalah seramai 800 orang murid yang berumur 16 tahun (lelaki $n=400$ dan perempuan $\mathrm{n}=400$ ) dari sekolah menengah kawasan bandar dan luar bandar dalam daerah Kuala Selangor. Instrumen tinjauan keterlibatan murid di sekolah (The Student Engagement Scale, Lam et al.,2009) merupakan instrumen yang digunakan untuk pengumpulan data. Analisis inferensi korelasi Pearson dan regresi berganda dijalankan untuk menentukan hubungan dan sumbangan antara pemboleh ubah. Analisis model persamaan berstruktur (SEM) dilaksanakan untuk mengenal pasti peranan keterlibatan sebagai perantara bagi faktor sokongan pembelajaran dan pencapaian akademik murid, mengikut gender.

Dapatan - Dapatan kajian menunjukkan hubungan yang signifikan antara keterlibatan murid, sokongan pembelajaran dan pencapaian 
akademik. Keterlibatan murid merupakan perantara bagi faktor sumbangan sokongan pembelajaran dan pencapaian akademik murid lelaki dan perempuan.

Kepentingan - Hasil kajian ini dapat mengukuhkan teori peranan sokongan pembelajaran terhadap pencapaian murid, perbezaan gender dalam keterlibatan agar program intervensi dapat ditambahbaik bagi meningkatkan keberhasilan keterlibatan murid.

Kata kunci: Gender, keterlibatan murid, sokongan pembelajaran, pencapaian.

\begin{abstract}
Purpose - The study examines the relationship between students' engagement, learning support and students' achievement by gender. It also examines the extent to which student engagement plays a role in mediating the relationship between learning support and students' achievement.

Methodology - Cross sectional surveys were used to collect data on student engagement at school, their learning support and academic achievement. The sample consisted of 800 students, aged 16 (400 boys and 400 girls) from secondary schools in urban and rural areas in the district of Kuala Selangor, Malaysia. The Student Engagement Scale (Lam et al., 2009) was used for data collection. Pearson correlations and multiple regression were conducted to determine the relationship between variables. Structural equation modeling (SEM) was carried out to assess the role of student engagement in mediating the support of teachers, peers and parents, and students' achievement by gender.
\end{abstract}

Findings - The findings show a significant relationship between student engagement, learning support and academic achievement. Student engagement has a mediating influence on learning support and the academic achievement of both genders.

Significance - The results of this study reinforces the theory on the role of learning support towards student achievement. Intervention programmes that increase the quality of learning support could be improved to enhance students' academic engagement and outcomes. 
Keywords: Gender, student engagement, learning support, achievement

\section{PENGENALAN}

Keterlibatan murid di sekolah adalah satu aspek pembelajaran dan perkembangan pelajar yang perlu diberi perhatian. Keterlibatan murid membawa maksud penglibatan murid secara aktif dalam aktiviti pembelajaran di dalam dan di luar bilik darjah (Trowler, 2010; Kuh, Kinzie, Buckley \& Bridges, 2007). Menurut Welch, \& Bonnan-White (2012), keterlibatan murid bermaksud murid menyertai pelbagai aktiviti seperti belajar, berinteraksi dengan guru dan rakan sebaya dan melibatkan diri dalam aktiviti di sekolah. Definisi di atas bermaksud keterlibatan murid di sekolah meliputi pelbagai ciri seperti tingkah laku, emosi, kognitif, dan penglibatan psikologi (Skinner \& Pitzer, 2012; Lam et al., 2012). Murid yang rendah tahap keterlibatan di sekolah sering dilihat sebagai satu tanda pengasingan diri. Hal ini boleh menyebabkan murid membina pelbagai bentuk dimensi negatif dalam diri mereka. Keterlibatan murid juga adalah peramal penting kepada pencapaian akademik murid. Secara tuntasnya, konsep keterlibatan bersandarkan kepada suatu teori yang luas dalam membina hubungan murid dengan sekolah atau konsep penglibatan sekolah (Fredricks, Blumenfeld \& Paris, 2004).

\section{PERNYATAAN MASALAH}

Pencapaian antara murid lelaki dan perempuan yang tidak seimbang merupakan satu fenomena sejagat (Rodriguez, 2003; Epstein, Elwood, Jey \& Maw, 1998). Masalah ketidakseimbangan ini telah dikaji oleh beberapa pengkaji Malaysia (Mohd Jelas, Rahman, Baki, \& Ahmad, 2005; Ahmad, Mohd Jelas \& Mohd Ali, 2011; Mohd Jelas, Salleh, Azman, Jani, Hamzah, Mahmud, Ab Hamid, Hamzah \& Zulnaidi, 2014). Dapatan kajian oleh Mohd Jelas, Mohd Yunus, Mohd Dahan \& Redzuan, (2001); Awang-Hashim, Hashim, Yaakub, Othman, \& Md Ali, (2004); Wang \& Holcombe (2010); Lam et al., (2012) mendapati murid perempuan mencapai prestasi akademik yang lebih baik daripada murid lelaki. Murid lelaki juga dikatakan kurang keterlibatan di sekolah serta rendah pencapaian akademik berbanding perempuan (Mohd Jelas et al., 2005; Awang-Hashim et 
al., 2004; Ahmad et al., 2011). Pencapaian akademik memihak kepada murid perempuan berbanding murid lelaki yang menyebabkan timbulnya isu ketidakseimbangan antara gender. Menurut Mohd Jelas et al., (2005); Veronneau \& Dishion (2011); Lam et al., (2012), isu ketidakseimbangan ini juga berkait dengan sokongan pembelajaran.

Dapatan hasil kajian Mohd Jelas et al., (2005) menunjukkan bahawa kesan gaya pembelajaran serta kemahiran dan strategi pembelajaran murid sekolah di Malaysia lebih memihak kepada murid perempuan berbanding murid lelaki. Dapatan Lam et al., (2012) berkaitan perbezaan gender dalam pencapaian murid sekolah di 12 negara juga menyokong dapatan Mohd Jelas et al., (2005) yang menunjukkan pencapaian murid perempuan adalah lebih tinggi daripada murid lelaki. Hal ini berlaku disebabkan oleh gaya serta kemahiran murid perempuan yang didapati sesuai dengan cara pengajaran guru perempuan serta cara persediaan diri mereka sebelum menghadapi peperiksaan (Mohd Jelas et al.,2005; Lam et al., 2012). Murid perempuan juga lebih mempercayai rakan sebaya untuk membantu mereka dalam aktiviti pembelajaran (Mohd Jelas et al., 2014; Lam et al., 2012).

Fenomena yang berlaku kini menunjukkan bahawa jurang pencapaian antara murid lelaki dan perempuan adalah ketara dalam perbezaan enrolmen pelajar lelaki dan perempuan yang berada di Institusi Pengajian Tinggi Awam (IPTA). ${ }^{1}$ Perbezaan enrolmen pelajar lelaki dan perempuan ini merupakan implikasi yang terhasil daripada isu jurang pencapaian antara gender di peringkat sekolah (Jadual 1).

Jadual 1

Pencapaian murid di sekolah Harian (SH) 2006, 2011 dan 2017

\begin{tabular}{ccc}
\hline TAHUN & \multicolumn{2}{c}{$\begin{array}{c}\text { Sekolah Harian } \\
\text { Gred Purata Nasional SPM }\end{array}$} \\
\hline & Lelaki & Perempuan \\
2006 & 6.16 & 5.50 \\
2011 & 5.58 & 4.72 \\
2017 & 5.41 & 4.58 \\
\hline & & $*$ GPN lebih rendah lebih baik.
\end{tabular}

Sumber: Lembaga Peperiksaan, Kementerian Pelajaran Malaysia.

${ }^{1}$ Institut Pengajian Tinggi Awam (IPTA) ialah Universiti Awam yang banyak dibiayai secara awam melalui kerajaan negara atau setempat. 
Jadual 2 menunjukkan perbezaan enrolmen pelajar lelaki dan perempuan di IPTAbagitahun 2015 dan2016berdasarkan gender. Data menunjukkan bahawa enrolmen pelajar perempuan adalah 389,173 orang $(59.40 \%)$ berbanding pelajar lelaki iaitu 266,063 orang $(40.60 \%)$ bagi tahun 2015 . Enrolmen pelajar di IPTA untuk tahun 2016 adalah seramai 387,600 orang $(59.46 \%)$ pelajar perempuan manakala pelajar lelaki seramai 264,232 orang (40.54\%). Perbezaan ini memberi implikasi yang besar di IPTA. Jurang perbezaan ini akan terus meningkat jika tahap rendah pencapaian murid lelaki di peringkat pendidikan menengah tidak di atasi.

Jadual 2

Enrolmen pelajar lelaki dan perempuan di IPTA tahun 2015 dan 2016

Bilangan penutut di IPTA, Malaysia tahun 2015 dan 2016

\begin{tabular}{ccccc}
\hline & $\begin{array}{c}\text { Lelaki } \\
(2015)\end{array}$ & $\begin{array}{c}\text { Perempuan } \\
(2015)\end{array}$ & $\begin{array}{c}\text { Lelaki } \\
(2016)\end{array}$ & $\begin{array}{c}\text { Perempuan } \\
(2016)\end{array}$ \\
\cline { 2 - 5 } & 266,063 & 389,173 & 264,232 & 387,600 \\
& $(40.60 \%)$ & $(59.40 \%)$ & $(40.54 \%)$ & $(59.46 \%)$ \\
\hline Jumlah & \multicolumn{2}{c}{655,236} & \multicolumn{2}{c}{651,832} \\
\hline
\end{tabular}

Sumber: Statistik Pendidikan Tinggi 2015 dan 2016: Kementerian Pengajian Tinggi Malaysia (Makro-Institusi Pendidikan Tinggi 2015 dan 2016)

Justeru, masih terdapat ruang untuk mengkaji fenomena jurang pencapaian antara pelajar lelaki dan perempuan dengan menggunakan pendekatan yang lebih komprehensif yang melibatkan peranan sokongan pembelajaran dan keterlibatan terhadap pencapaian murid mengikut gender. Kertas ini melaporkan satu kajian yang berusaha untuk meningkatkan kefahaman terhadap peranan sokongan pembelajaran terhadap pencapaian berdasarkan perbezaan gender dalam keterlibatan pembelajaran mereka.

\section{TINJAUAN LITERATUR}

Tinjauan literatur mengenai keterlibatan murid di sekolah telah menunjukkan konsensus bahawa konstruk tersebut merupakan satu 
konstruk pelbagai dimensi yang penting dan relevan untuk meninjau fikiran, perasaan dan tingkah laku murid terhadap pembelajaran dan persekolahan (Fredericks, Blumenfeld \& Paris, 2004; Furlong \& Christenson, 2008; Lam et al. 2012). Beberapa kajian juga telah menunjukkan bahawa keterlibatan murid adalah peramal prestasi akademik (Vasalampi, Salmela-Aro \& Nurmi, 2009; Wu, Hughes \& Kwok, 2010; Wang \& Holcombe, 2010; Wang \& Eccles, 2012; Md Jaafar, Awang-Hashim \& Tengku Ariffin, 2012). Kajian-kajian lepas jelas menunjukkan bahawa keterlibatan murid adalah satu ciri psikologikal yang dipengaruhi oleh faktor kontekstual, seperti iklim bilik darjah, sokongan ibu bapa dan pengaruh rakan sebaya yang merupakan ekosistem pembelajaran murid tersebut. Hal ini adalah bersesuaian dengan teori produktiviti pendidikan Walberg (1981) yang menyatakan bahawa ciri psikologikal murid dan persekitaran mempengaruhi hasil pendidikan mereka dan ekosistem tersebut berfungsi sebagai 'pemboleh akademik' (academic enablers) dan peramal penting pencapaian akademik murid (DiPerna, Volpe \& Elliott, 2002).

Kajian lepas juga telah banyak menumpukan kepada perbezaan gender dalam keterlibatan murid di sekolah. Sebagai contoh, kajian Lam et al.,(2012) telah mengkaji peranan keterlibatan murid di sekolah berdasarkan gender di 12 negara manakala kajian Mohd Jelas et al., (2014) pula mengkaji peranan keterlibatan murid di sekolah sebagai perantara gender yang berlatar belakangkan murid lingkungan umur 12 hingga 16 tahun di Malaysia. Secara umumnya, tinjauan literatur mengenai keciciran murid telah membuktikan bahawa selain sokongan guru, rakan sebaya dan ibu bapa juga merupakan peramal penting kepada keterlibatan dan pencapaian sekolah (Rumberger \& Sun, 2008; Yazzie-Mintz, 2009).

\section{Keterlibatan Murid di Sekolah}

Keterlibatan murid bermaksud murid aktif dalam setiap aktiviti sekolah secara bersungguh-sungguh untuk mempelajari apa yang ditawarkan di sekolah sama ada pembelajaran formal dan tidak formal. Murid yang tidak mempunyai keterlibatan di sekolah lebih cenderung terjebak dengan gejala tidak sihat di luar sekolah (Jozefowicz, Colarossi, Arbreton, Eccles \& Barber, 2000). Daripada tinjauan literatur, dapat dirumuskan bahawa keterlibatan murid di sekolah bergantung kepada peranan yang dimainkan oleh sekolah itu sendiri (Rumberger \& Sun, 2008; Rumberger, 2011). 
Secara umumnya, keterlibatan murid di sekolah meliputi tiga faktor atau domain yang merupakan dimensi paling kritikal untuk mengukur keterlibatan murid di sekolah iaitu keterlibatan afektif, keterlibatan tingkah laku dan keterlibatan kognitif (Fredricks, Blumenfeld \& Paris, 2004; Lam, et al., 2012). Keterlibatan murid menurut Fredricks, Blumenfeld \& Friedel (2005) dan Lam et al., (2012) adalah gabungan tiga konstruk iaitu keterlibatan afektif, keterlibatan tingkah laku dan keterlibatan kognitif yang boleh menjelaskan bagaimana seseorang murid itu berkelakuan, berperasaan dan berfikir di sekolah.

Keterlibatan afektif diertikan sebagai perasaan dan emosi murid terhadap sesuatu pembelajaran (Skinner \& Belmont, 1993) dan sekolah yang mereka hadir. Perasaan keberadaan murid di sekolah termasuklah perasaan terhadap guru dan rakan sebaya. Ia menggambarkan perasaan gembira murid dan kesungguhan dalam melaksanakan tugasan sekolah dan tugas lain yang diamanahkan. Selain itu, perasaan negatif seperti rasa takut, bimbang dan bosan juga menggambarkan emosi mereka. Menurut Lam et al., (2012), perasaan seseorang murid tentang aktiviti pembelajaran mencerminkan motivasi intrinsik manakala perasaan tentang sekolah adalah manisfitasi kepada ikatan sekolah. Murid yang mengalami keterlibatan afektif tinggi merasa seronok belajar dan gembira pergi ke sekolah.

Keterlibatan tingkah laku murid ditakrifkan sebagai peruntukan masa kepada tugas, tingkah laku murid semasa belajar, kehadiran mereka ke kelas dan sekolah serta murid bertindak aktif dalam perbincangan kelas. Menurut Lam et al., (2012), keterlibatan tingkah laku merujuk kepada murid yang mempunyai keterlibatan di sekolah dalam mempelajari aktiviti kurikulum dan kokurikulum di mana mereka rajin dalam pembelajaran di bilik darjah dan aktif aktiviti kokurikulum.

Keterlibatan kognitif pula merujuk kepada jumlah dan jenis strategi kognitif yang digunakan oleh murid. Ia lebih menekankan kepada keterlibatan yang melibatkan intelek dan penguasaan murid terhadap akademik, usaha, hasil mereka dalam kerja dan strategi pembelajaran. Dalam aktiviti pembelajaran, murid menggunakan strategi pemerosesan mendalam atau strategi pemerosesan permukaan. Pemerosesan mendalam dikaitkan dengan elaborasi kognitif bahan yang dipelajari, manakala pemerosesan permukaan melibatkan ingatan dan hafalan, ulangan latihan dan aktiviti lain 
yang melibatkan hubungan cetek dengan bahan yang dipelajari. Murid yang mengalami pemerosesan mendalam mempunyai fahaman dan pengekalan bermakna terhadap bahan yang dipelajari. Secara ringkasnya, keterlibatan kognitif disifatkan sebagai satu ciri individu yang memudahkan interaksi dalam konteks sekolah dan menggalakkan keterlibatan murid (Mahatmya, Lohman, Matjasco \& Farb, 2012).

\section{Sokongan Pembelajaran}

Keterlibatan murid dalam sekolah memerlukan sokongan daripada guru, rakan sebaya dan ibu bapa kerana ia dapat menentukan tahap pencapaian murid. Penelitian terhadap peranan sokongan pembelajaran dalam keterlibatan murid dan perbezaan gender terhadap pencapaian murid di sekolah merupakan satu dimensi dalam usaha untuk mengenal pasti pencapaian murid di sekolah supaya tindakan untuk mengatasi masalah perbezaan jurang antara gender dapat dilakukan.

Ketiga-tiga konstruk ini merupakan dimensi paling kritikal untuk mengukur keterlibatan murid di sekolah. Setiap konstruk juga telah dikaji secara berasingan yang membuktikan bahawa keterlibatan murid di sekolah adalah peramal penting penyertaan dan pencapaian dalam kalangan murid (Mohd Jelas et al., 2005; Chen 2008; Bempechat \& Shernoff 2012).

\section{Sokongan Pembelajaran Guru}

Guru adalah sokongan pembelajaran yang mendorong kepada keterlibatan murid di sekolah (Willms, 2003; Fredricks et al., 2005; Lam et al., 2012). Hubungan guru dengan murid merupakan faktor yang signifikan dalam meningkatkan komitmen belajar (Arbaa, Jamil, \& Abd Razak, 2010; Brooks, Brooks \& Goldstein, 2012). Hubungan antara guru dengan murid menggalakkan keterlibatan mereka di sekolah dan hal ini akan meningkatkan motivasi dan pencapaian murid dalam pelajaran (Lam et al., 2012). Murid juga akan lebih komited dan berusaha untuk berjaya jika murid mempunyai guru yang peka terhadap masalah dan keperluan murid (Mearns et al.,2007). Kajian lepas juga muktamad dalam menjelaskan bahawa kanakkanak dan remaja yang mengalami rasa dihargai guru menunjukkan keterlibatan emosi dan tingkah laku positif di sekolah (Furrer \& Skinner, 2003; Roorda, Koomen, Spilt \& Oort, 2011). Oleh yang demikian, sokongan sosial dan emosi guru terhadap murid perlulah 
kondusif untuk meningkatkan keterlibatan murid di sekolah. Rasa keanggotaan murid di kelas dan di sekolah dapat diperkukuhkan jika guru memberi perhatian dan mengambil berat terhadap perasaan murid (Pianta, Hamre \& Allen, 2012; Croninger \& Lee, 2001).

\section{Sokongan Pembelajaran Rakan Sebaya}

Rakan sebaya merupakan agen sosialisasi penting murid terutama di peringkat remaja. Rakan sebaya dengan keterlibatan sekolah yang tinggi mempunyai sikap yang positif tentang sekolah. Justeru, penerimaan dan pergaulan antara murid dengan rakan sebaya dalam sekolah dapat membantu mereka dalam pembelajaran dan meningkatkan rasa kepunyaan serta dihargai (Eccles \& Barber, 1999). Sokongan rakan sebaya juga dapat menggalakkan murid untuk belajar dan meningkatkan pencapaian akademik mereka (Bandura, 1989). Selain itu, rakan di sekolah juga boleh dijadikan sasaran untuk sesuatu perbandingan sosial dan pencapaian akademik. Pencapaian akademik yang baik boleh dijangkakan mempunyai signifikan sama ada positif atau negatif pada penilaian efikasi kendiri murid, tingkah laku dan pencapaian akademik mereka (Veronneau \& Dishion, 2011). Menurut Lam et al., (2012) dan Wang \& Holcombe (2010), perkaitan di antara sokongan rakan sebaya dan prestasi akademik adalah lemah untuk murid lelaki tetapi lebih kukuh bagi murid perempuan. Walau bagaimanapun, jika murid mempunyai sokongan yang tinggi daripada rakan sebaya, mereka akan lebih terlibat dan aktif menjalankan aktiviti di sekolah. Menurut Veronneau \& Dishion (2011), kesan interaksi bersama rakan sebaya adalah signifikan antara pencapaian akademik seseorang murid dengan pencapaian akademik rakan-rakan mereka tetapi hanyalah pada murid perempuan sahaja.

\section{Sokongan Pembelajaran Ibu bapa}

Ibu bapa merupakan model utama bagi seseorang anak sebelum mereka melalui alam persekolahan. Justeru, Ibu bapa memainkan peranan yang penting dalam keterlibatan murid di sekolah dan pencapaian akademik mereka. Sokongan dan hubungan dengan ibu bapa juga berupaya mengurangkan murid dari berpencapaian rendah (Bempechat \& Shernoff, 2012). Kajian Chohan \& Khan (2010) mendapati sokongan ibu bapa dalam melakukan kerja rumah dan aktiviti akademik yang lain mempunyai kesan yang besar ke atas tingkah laku dan pencapaian prestasi akademik murid. Jelas bahawa ibu bapa yang menyediakan sokongan akademik seperti bantuan 
dalam kerja sekolah di rumah dan sokongan motivasi, seperti berbincang mengenai sekolah dan memantau kegiatan anak-anak dapat menyumbang kepada prestasi akademik anak mereka.

\section{TUJUAN KAJIAN}

Kajian ini bertujuan untuk meninjau peranan keterlibatan murid sebagai perantara bagi hubungan antara faktor sokongan pembelajaran dan pencapaian akademik, mengikut gender. Dapatan kajian berkaitan peranan keterlibatan dan sokongan pembelajaran terhadap pencapaian murid adalah penting supaya perancangan yang strategik dapat dilaksanakan bagi mengurangkan jurang perbezaan pencapaian antara gender.

Kajian ini hanya melibatkan murid sekolah menengah kebangsaan di bandar dan luar bandar yang berumur 16 tahun dalam daerah Kuala Selangor. Berlainan dengan kajian Mohd Jelas et al.,(2014), kajian ini hanya memfokuskan kepada remaja berumur 16 tahun kerana remaja pada tahap ini sedang melalui proses peralihan daripada awal remaja ke remaja. Remaja pada tahap ini melalui waktu yang kompleks yang mana mereka melalui perubahan yang ketara khususnya dalam aspek pembentukan identiti (Ahmad, 2000). Daerah Kuala Selangor pula dipilih kerana ia berada pada kedudukan ke lapan dari sepuluh daerah di negeri Selangor berdasarkan pencapaian SPM2 tahun 2009, 2010, 2012 dan 2013.

Kajian ini turut menguji sama ada dapatan yang diperoleh dapat menyokong kajian Mohd Jelas et al., (2014) serta kajian lepas dari dalam dan luar negara. Ini adalah supaya implikasi dan cadangan amalan dapat meningkatkan keberhasilan keterlibatan akademik murid bersesuaian dengan budaya dalam masyarakat setempat di Malaysia. Maka, kajian ini adalah penting kerana ia menguji teori peranan sokongan pembelajaran terhadap pencapaian murid dan perbezaan gender dalam keterlibatan khususnya dalam konteks pendidikan dan budaya Malaysia agar program intervensi dapat ditambah baik bagi meningkatkan keberhasilan keterlibatan murid.

2 Sijil Pelajaran Malaysia atau SPM ialah sejenis peperiksaan yang dianjurkan oleh Lembaga Peperiksaan Malaysia. Ia merupakan syarat untuk pelajar di Malaysia untuk menyambung pelajaran ke peringkat pra-universiti. 
Kajian ini mengandaikan bahawa keterlibatan dan pencapaian murid di peringkat pendidikan menengah dipengaruhi oleh sejauh mana peranan keterlibatan murid di sekolah dan sejauh mana persepsi murid terhadap sokongan guru, rakan sebaya dan ibu bapa mempengaruhi keterlibatan dan pencapaian akademik mereka di sekolah.

\section{OBJEKTIF DAN SOALAN KAJIAN}

\section{Objektif Kajian}

1. Meninjau hubungan keterlibatan murid, sokongan pembelajaran dan pencapaian akademik mengikut gender.

2. Meneliti sama ada terdapat peranan keterlibatan sebagai perantara bagi hubungan faktor sokongan pembelajaran dan pencapaian murid mengikut gender.

\section{Soalan Kajian}

1. Adakah terdapat hubungan keterlibatan murid dan sokongan pembelajaran dengan pencapaian akademik mengikut gender?

2. Adakah terdapat peranan keterlibatan sebagai perantara sumbangan antara sokongan guru, rakan sebaya dan ibu bapa terhadap pencapaian murid mengikut gender?

\section{KERANGKA KONSEP}

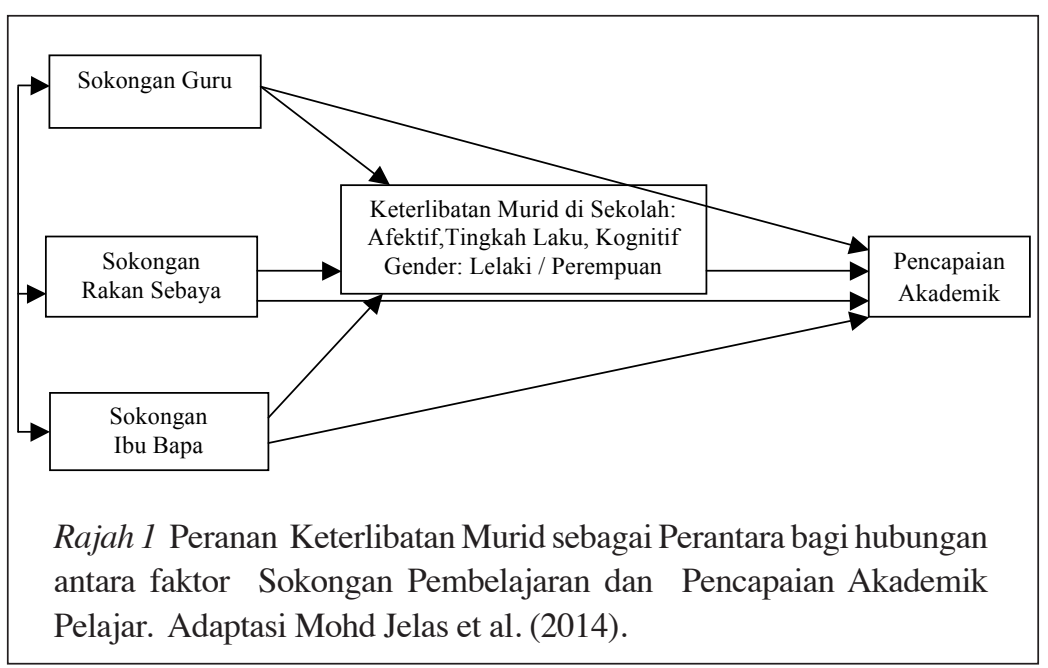


Berdasarkan Rajah 1, kerangka konseptual menerangkan peranan sokongan pembelajaran dalam keterlibatan murid berdasarkan gender terhadap pencapaian. Kerangka konseptual kajian ini memberi gambaran tentang hubungan antara beberapa pemboleh ubah. Kajian ini mengandaikan bahawa sokongan pembelajaran dan keterlibatan murid mempengaruhi pencapaian akademik murid di mana keterlibatan dipostulasikan sebagai perantara. Faktor gender merujuk kepada murid lelaki dan perempuan yang berada di tingkatan empat sekolah menengah kebangsaan bercampur gender. Secara khususnya, kerangka konseptual kajian ini memberi petunjuk mengenai perancangan kajian ini selaras dengan objektif yang dikaji.

\section{METODOLOGI}

\section{Rekabentuk kajian}

Kajian ini menggunakan kaedah tinjauan kuantitatif yang melibatkan pengujian model persamaan berstuktur. Ianya melibatkan kajian tinjauan dengan menggunakan soal selidik yang diedarkan kepada responden bagi mendapatkan data yang diperlukan.

\section{Sampel}

Populasi kajian adalah murid tingkatan empat yang berumur 16 tahun, dari sekolah menengah kebangsaan dalam daerah Kuala Selangor.3 Enrolmen populasi kajian diambil dari Pejabat Pendidikan Daerah Kuala Selangor (PPDKS) bagi tahun 2017. Jumlah keseluruhan murid tingkatan empat sekolah menengah kebangsaan dalam daerah Kuala Selangor adalah seramai 3,214 orang (lelaki $\mathrm{n}=1,590$ orang, perempuan $\mathrm{n}=1,624$ orang). Sampel kajian telah dipilih melalui kaedah persampelan rawak berstrata berdasarkan murid berpencapaian tinggi dan murid berpencapaian rendah. Bilangan sampel murid lelaki dan perempuan adalah sama rata iaitu seramai 400 orang $(n=800)$.

\section{Instrumen Kajian}

Soal selidik dan konstruk keterlibatan murid di sekolah dan sokongan pembelajaran (The Student Engagement Scale, Lam et

${ }^{3}$ Kuala Selangor merupakan salah sebuah daerah pendidikan dalam Negeri Selangor, Malaysia. 
al., 2009) yang digunakan dalam kajian ini telah diterjemahkan dan diadaptasi oleh Mohd Jelas et al., (2014); Mohd Jelas, Azman, Zulnaidi, Ahmad (2016). Kebolehpercayaan terjemahan soal selidik adalah tinggi: nilai korelasi split half antara versi Bahasa Melayu dan versi Bahasa Inggeris adalah 0.73. Instrumen ini juga telah diuji kebolehpercayaannya oleh Mohd Jelas et al., $(2014,2016)$ ke atas 4,860 orang remaja yang berumur antara 12 hingga 16 tahun. Analisis Cronbach Alpha bagi konstruk keterlibatan murid di sekolah adalah 0.85. Bagi sokongan guru adalah 0.81, sokongan ibu bapa adalah 0.75 dan sokongan rakan sebaya adalah 0.68 . Pencapaian akademik diperoleh dari nilai purata gred murid dalam mata pelajaran teras di sekolah. Instrumen tersebut terdiri daripada tiga bahagian yang diukur berdasarkan skala likert lima titik seperti jadual 3 .

\section{Jadual 3}

Perincian item soalan selidik dimensi keterlibatan dan sokongan pembelajaran

\begin{tabular}{|c|c|c|c|}
\hline Bahagian & $\begin{array}{l}\text { Dimensi keterlibatan / } \\
\text { sokongan pembelajaran }\end{array}$ & $\begin{array}{l}\text { Jumlah } \\
\text { Item }\end{array}$ & Contoh Item \\
\hline A & Maklumat demografi & 7 & $\begin{array}{l}\text { - Jantina : 1 Lelaki } \\
\text { 2 Perempuan } \\
\text { - Tinggal bersama: } \\
\text { 1 Ibu dan bapa kandung } \\
2 \text { Ibu kandung dan bapa } \\
\text { tiri } \\
3 \text { Bapa kandung dan ibu } \\
\text { tiri } \\
4 \text { Penjaga (nyatakan) }\end{array}$ \\
\hline \multirow[t]{2}{*}{ B } & Keterlibatan afektif & 9 & $\begin{array}{l}\text { - Saya sangat berminat } \\
\text { dengan pembelajaran. } \\
\text { - Saya fikir apa yang saya } \\
\text { pelajari di sekolah adalah } \\
\text { menarik. }\end{array}$ \\
\hline & $\begin{array}{l}\text { Keterlibatan Tingkah } \\
\text { laku }\end{array}$ & 12 & $\begin{array}{l}\text { - Saya berusaha dengan } \\
\text { gigih untuk berjaya di } \\
\text { sekolah. } \\
\text { - Semasa di dalam kelas, } \\
\text { saya mengambil bahagian } \\
\text { dalam aktiviti kelas. }\end{array}$ \\
\hline
\end{tabular}




\begin{tabular}{|c|c|c|c|}
\hline Bahagian & $\begin{array}{c}\text { Dimensi keterlibatan / } \\
\text { sokongan pembelajaran }\end{array}$ & $\begin{array}{l}\text { Jumlah } \\
\text { Item }\end{array}$ & Contoh Item \\
\hline \multirow{4}{*}{$\mathrm{C}$} & Keterlibatan Kognitif & 12 & $\begin{array}{l}\text { - Semasa belajar, saya } \\
\text { cuba memahami apa yang } \\
\text { dipelajari secara } \\
\text { mengaitkan perkara itu } \\
\text { dengan perkara yang telah } \\
\text { saya ketahui. } \\
\text { - Semasa mempelajari } \\
\text { maklumat baru, saya } \\
\text { cuba memikirkannya } \\
\text { dalam bahasa saya sendiri. }\end{array}$ \\
\hline & Sokongan guru & 3 & $\begin{array}{l}\text { Di sekolah saya, terdapat } \\
\text { guru yang mengambil } \\
\text { berat tentang saya. } \\
\text { - Di sekolah saya, terdapat } \\
\text { guru yang baik dengan } \\
\text { saya. }\end{array}$ \\
\hline & Sokongan rakan sebaya & 3 & $\begin{array}{l}\text { - Di sekolah saya, saya } \\
\text { mempunyai kawan yang } \\
\text { mengambil berat tentang } \\
\text { saya. } \\
\text { - Di sekolah saya, saya } \\
\text { mempunyai rakan yang } \\
\text { membantu apabila saya } \\
\text { menghadapi situasi yang } \\
\text { sukar. }\end{array}$ \\
\hline & Sokongan ibu bapa & 8 & $\begin{array}{l}\text { - Bertanya tentang sekolah } \\
\text { saya. } \\
\text { - Menggalakkan saya untuk } \\
\text { berusaha bersungguh- } \\
\text { sungguh di sekolah. }\end{array}$ \\
\hline
\end{tabular}

\section{Analisis Data}

Bagi menjawab objektif pertama, analisis inferensi korelasi Pearson dijalankan untuk menentukan hubungan di antara keterlibatan murid dengan sokongan pembelajaran mengikut gender dan hubungan keterlibatan murid dengan pencapaian akademik mengikut gender. Bagi mentafsirkan kekuatan hubungan antara pemboleh ubah yang dikaji, pengkaji menggunakan cadangan skor oleh Joseph et al., (1997) iaitu bawah 0.10 (lemah); 0.10-0.30 (sederhana) dan 0.30 ke atas (kuat). Objektif kedua menjawab persoalan kajian tentang peranan keterlibatan sebagai perantara sokongan guru, rakan sebaya dan ibu bapa terhadap pencapaian murid mengikut gender 
menggunakan Analisis Model Persamaan Berstruktur (SEM). Analisis SEM digunakan untuk meninjau hubungan langsung dan tidak langsung antara sokongan pembelajaran dan keterlibatan murid di sekolah dengan pencapaian murid lelaki dan perempuan.

\section{DAPATAN KAJIAN}

\section{Hubungan Keterlibatan Murid dengan Pencapaian Akademik Mengikut Gender}

Jadual 4 membentangkan statistik inferensi ketiga-tiga pemboleh ubah keterlibatan dengan pencapaian akademik murid berdasarkan gender. Ujian Korelasi Pearson dijalankan bagi mengenal pasti hubungan keterlibatan murid dengan pencapaian akademik berdasarkan gender. Secara keseluruhannya, dapatan analisis korelasi menunjukkan bahawa terdapat hubungan yang signifikan antara keterlibatan murid dengan pencapaian akademik berdasarkan gender. Murid perempuan menunjukkan hubungan yang lebih tinggi ( $\min =3.79)$ berbanding murid lelaki $(\min =3.61)$.

Berdasarkan analisis korelasi, dapatan menunjukkan tidak terdapat hubungan keterlibatan afektif dengan pencapaian bagi murid lalaki $(\mathrm{r}=0.095$ dan sig=0.056( $\mathrm{p}>0.05)$. Bagaimanapun, terdapat hubungan yang signifikan antara keterlibatan tingkah laku murid lelaki dengan pencapaian akademik dengan nilai $\mathrm{r}=0.218 \mathrm{dan} \operatorname{sig}=0.001(\mathrm{p}<0.05)$. Seterusnya, terdapat hubungan yang signifikan antara keterlibatan kognitif murid lelaki dengan pencapaian akademik dengan nilai $\mathrm{r}=0.224 \mathrm{dan} \operatorname{sig}=0.001(\mathrm{p}<0.05)$. Kekuatan hubungan bagiketerlibatan tingkah laku dan kognitif bagi murid lelaki adalah di tahap positif rendah. Manakala bagi murid perempuan, terdapat hubungan yang signifikan antara keterlibatan afektif dengan pencapaian akademik dengan nilai $(\mathrm{r}=0.140$ dan $\mathrm{sig}=0.005(\mathrm{p}<0.05)$. Kekuatan hubungan adalah pada tahap positif rendah. Selain itu, terdapat hubungan yang signifikan antara keterlibatan tingkah laku murid perempuan dengan pencapaian akademik $(r=0.225$ dan sig $=0.001, \mathrm{p}<0.05)$ yang menunjukkan kekuatan hubungan pada tahap positif rendah. Seterusnya, terdapat hubungan yang signifikan antara keterlibatan kognitif murid perempuan dengan pencapaian akademik dengan nilai $\mathrm{r}=0.255$ dan $\operatorname{sig}=0.001(\mathrm{p}<0.05)$. Kekuatan hubugan ini juga adalah pada tahap positif rendah. 
Jadual 4

Korelasi Pearson hubungan keterlibatan murid dengan pencapaian akademik mengikut gender

\begin{tabular}{|c|c|c|c|c|c|c|c|c|}
\hline & \multirow{3}{*}{$\begin{array}{c}\mathrm{L} \\
\text { Min }\end{array}$} & \multirow{3}{*}{$\begin{array}{c}\mathrm{P} \\
\text { Min }\end{array}$} & \multicolumn{6}{|c|}{ Pencapaian akademik } \\
\hline & & & \multicolumn{3}{|c|}{ Lelaki } & \multicolumn{3}{|c|}{ Perempuan } \\
\hline & & & $\mathrm{r}$ & Sig. & Interp. & $\mathrm{r}$ & Sig. & Interp. \\
\hline Afektif & 3.70 & 3.82 & 0.095 & 0.056 & - & 0.140 & 0.005 & Rendah \\
\hline Tingkah & 3.58 & 3.85 & 0.218 & 0.000 & Rendah & 0.225 & 0.000 & Rendah \\
\hline laku & & & & & & & & \\
\hline Kognitif & 3.56 & 3.69 & 0.224 & 0.000 & Rendah & 0.255 & 0.000 & Rendah \\
\hline Keseluruhan & 3.61 & 3.79 & & & & & & \\
\hline
\end{tabular}

\section{Hubungan Sokongan Pembelajaran Murid dengan Pencapaian Akademik Mengikut Gender.}

Jadual 5 menunjukkan keputusan ujian korelasi Pearson bagi melihat hubungan antara sokongan pembelajaran murid dengan pencapaian akademik mengikut gender. Skor min guru bagi murid lelaki adalah 3.71 dan perempuan 3.83 sementara, skor min rakan sebaya murid lelaki adalah 3.84 dan perempuan 4.22. Skor min sokongan ibu bapa murid lelaki pula adalah 3.98 dan perempuan 4.06. Secara keseluruhannya, murid perempuan memberikan skor min yang lebih tinggi $(\mathrm{min}=4.05)$ kepada sokongan pembelajaran berbanding murid lelaki pada nilai min sederhana $(\min =3.90)$. Dapatan analisis korelasi menunjukkan terdapat hubungan yang signifikan antara sokongan pembelajaran murid dengan pencapaian akademik mengikut gender. Hasil analisis data menunjukkan terdapat hubungan yang signifikan antara sokongan pembelajaran guru dalam kalangan murid lelaki dengan pencapaian akademik $(\mathrm{r}=0.312$ dan sig=0.001 $\mathrm{p}<0.05)$. Kekuatan hubungan ialah pada tahap positif sederhana. Bagi hubungan sokongan pembelajaran rakan sebaya dalam kalangan murid lelaki dengan pencapaian akademik pula, terdapat hubungan yang signifikan antara sokongan pembelajaran rakan sebaya dalam kalangan murid lelaki dengan pencapaian akademik dengan nilai $r=$ 0.272 dan sig $=0.001(\mathrm{p}<0.05)$. Seterusnya, terdapat hubungan yang signifikan antara sokongan pembelajaran ibu bapa dalam kalangan murid lelaki dengan pencapaian akademik dengan nilai $r=0.297$ dan $\operatorname{sig}=0.001(\mathrm{p}<0.05)$. Ini bermakna kekuatan hubungan sokongan 
pembelajaran rakan sebaya dan sokongan pembelajaran ibu bapa dalam kalangan murid lelaki dengan pencapaian akademik adalah pada tahap positif rendah.

Analisis korelasi Pearson pula menunjukkan terdapat hubungan yang signifikan antara sokongan pembelajaran guru dalam kalangan murid perempuan dengan pencapaian akademik $(r=0.226$ dan sig $=0.001, \mathrm{p}<0.05)$ dan hubungan yang signifikan antara sokongan pembelajaran rakan sebaya dalam kalangan murid perempuan dengan pencapaian akademik $(r=0.206, \mathrm{sig}=0.001, \mathrm{p}<0.05)$. Seterusnya, terdapat hubungan yang signifikan antara sokongan pembelajaran ibu bapa dalam kalangan murid perempuan dengan pencapaian akademik dengan nilai $\mathrm{r}=0.250$, sig $=0.001(\mathrm{p}<0.05)$. Kekuatan hubungan bagi ketiga-tiga hubungan sokongan pembelajaran murid perempuan dengan pencapaian akademik adalah pada tahap positif rendah.

\section{Jadual 5}

Korelasi Pearson hubungan sokongan pembelajaran murid dengan pencapaian akademik mengikut gender

\begin{tabular}{lccccccccc}
\hline & & \multicolumn{1}{c}{ Pencapaian akademik } \\
& L & P & \multicolumn{4}{c}{ Lelaki } & & Perempuan \\
& Min & Min & r & Sig. & Interp. & r & Sig. & Interp. \\
\hline Guru & 3.71 & 3.83 & 0.312 & 0.000 & Sederhana & 0.226 & 0.000 & Rendah \\
Rakan sebaya & 3.84 & 4.22 & 0.272 & 0.000 & Rendah & 0.206 & 0.000 & Rendah \\
Ibu bapa & 3.98 & 4.06 & 0.297 & 0.000 & Rendah & 0.250 & 0.000 & Rendah \\
Keseluruhan & 3.90 & 4.05 & & & & & & \\
\hline
\end{tabular}

\section{Sumbangan sokongan guru dan sokongan ibu bapa terhadap pencapaian akademik mengikut gender}

Jadual 6 menunjukkan sokongan guru menyumbang sebanyak 9.7 peratus $(\beta=0.394, \mathrm{t}=4.129$, Sig $=0.001$ dan $\mathrm{R} 2=0.097)$ dan sokongan ibu bapa menyumbang sebanyak 2.9 peratus $(\beta=0.392, \mathrm{t}$ $=3.620$, Sig $=0.001$ dan $\mathrm{R} 2=0.126$ ). kepada pencapaian akademik murid lelaki. Baki peratusan yang $(87.4 \%)$ lagi disumbangkan oleh faktor-faktor lain terhadap pencapaian akademik murid lelaki yang tidak diambil kira dalam kajian ini (Pallant 2005). 
Jadual 6

Regresi berganda sumbangan sokongan guru dan sokongan ibu bapa terhadap pencapaian akademik murid lelaki

\begin{tabular}{|c|c|c|c|c|c|c|c|}
\hline \multirow[b]{2}{*}{ Pembolehubah } & \multicolumn{2}{|c|}{$\begin{array}{l}\text { Unstandardized } \\
\text { Coefficients }\end{array}$} & \multirow{2}{*}{$\begin{array}{c}\text { Standardized } \\
\text { Coefficients } \\
\text { Beta }\end{array}$} & \multirow[b]{2}{*}{$\mathrm{T}$} & \multirow[b]{2}{*}{ Sig. } & \multirow[b]{2}{*}{$\mathrm{R}^{2}$} & \multirow{2}{*}{ Sumbangan } \\
\hline & $\beta$ & $\begin{array}{c}\text { Ralat } \\
\text { Piawai }\end{array}$ & & & & & \\
\hline Guru & 0.394 & 0.095 & 0.220 & 4.129 & 0.001 & 0.097 & $9.7 \%$ \\
\hline Ibu bapa & 0.392 & 0.108 & 0.193 & 3.620 & 0.001 & 0.126 & $2.9 \%$ \\
\hline Pemalar & 2.440 & 0.417 & & 5.848 & 0.001 & & \\
\hline
\end{tabular}

Jadual 7 menunjukkan sokongan ibubapa menyumbang sebanyak 6.2 peratus $(\beta=0.394, t=3.960, \operatorname{Sig}=0.001$ dan $\mathrm{R} 2=0.062)$ dan sokongan guru menyumbang sebanyak 2.5 peratus $(\beta=0.333, \mathrm{t}=$ 3.270, Sig=0 001 dan $\mathrm{R} 2=0.087$ ). kepada pencapaian akademik murid perempuan. Baki peratusan $(91.3 \%)$ disumbangkan oleh faktor-faktor lain terhadap pencapaian akademik murid perempuan yang tidak diambil kira dalam kajian ini (Pallant 2005).

Jadual 7

Regresi berganda sumbangan sokongan guru dan sokongan ibu bapa terhadap pencapaian akademik murid perempuan

\begin{tabular}{|c|c|c|c|c|c|c|c|}
\hline \multirow[b]{2}{*}{ Pembolehubah } & \multicolumn{2}{|c|}{$\begin{array}{l}\text { Unstandardized } \\
\text { Coefficients }\end{array}$} & \multirow{2}{*}{$\begin{array}{c}\text { Standardized } \\
\text { Coefficients } \\
\text { Beta }\end{array}$} & \multirow[b]{2}{*}{$\mathrm{T}$} & \multirow[b]{2}{*}{ Sig. } & \multirow[b]{2}{*}{$\mathrm{R}^{2}$} & \multirow{2}{*}{ Sumbangan } \\
\hline & $\beta$ & $\begin{array}{l}\text { Ralat } \\
\text { Piawai }\end{array}$ & & & & & \\
\hline Guru & 0.394 & 0.099 & 0.199 & 3.960 & 0.001 & 0.062 & $6.2 \%$ \\
\hline Ibu bapa & 0.333 & 0.102 & 0.165 & 3.270 & 0.001 & 0.087 & $2.5 \%$ \\
\hline Pemalar & 2.734 & 0.482 & & 5.675 & 0.001 & & \\
\hline
\end{tabular}

Keterlibatan Sebagai Perantara bagi hubungan faktor Sokongan Guru, Rakan Sebaya dan Ibu bapa, dengan Pencapaian Murid Mengikut Gender

i. Keterlibatan sebagai perantara bagi hubungan faktor sokongan guru, rakan sebaya dan ibu bapa dan pencapaian murid lelaki 
Untuk menguji sama ada keterlibatan murid di sekolah adalah perantara bagi hubungan faktor sokongan guru, rakan sebaya dan ibu bapa dan pencapaian akademik murid lelaki, analisis perantaraan menggunakan SEM telah dijalankan. Keputusan analisis laluan model persamaan SEM menggunakan AMOS menunjukkan ukuran Chi Square/ $\mathrm{df}=5.50$, Root Mean Square Error Approximation (RMSEA $)=0.04$, Goodness of Fit Index $(\mathrm{GFI})=0.93$ dan Comparative Fit Index $(\mathrm{CFI})=0.91$. Kesemua jenis ukuran penilaian yang digunakan menunjukkan bahawa data yang digunakan dalam kajian ini terbukti mempunyai penyesuaian munasabah bagi model yang dicadangkan (Byrne, 2010).

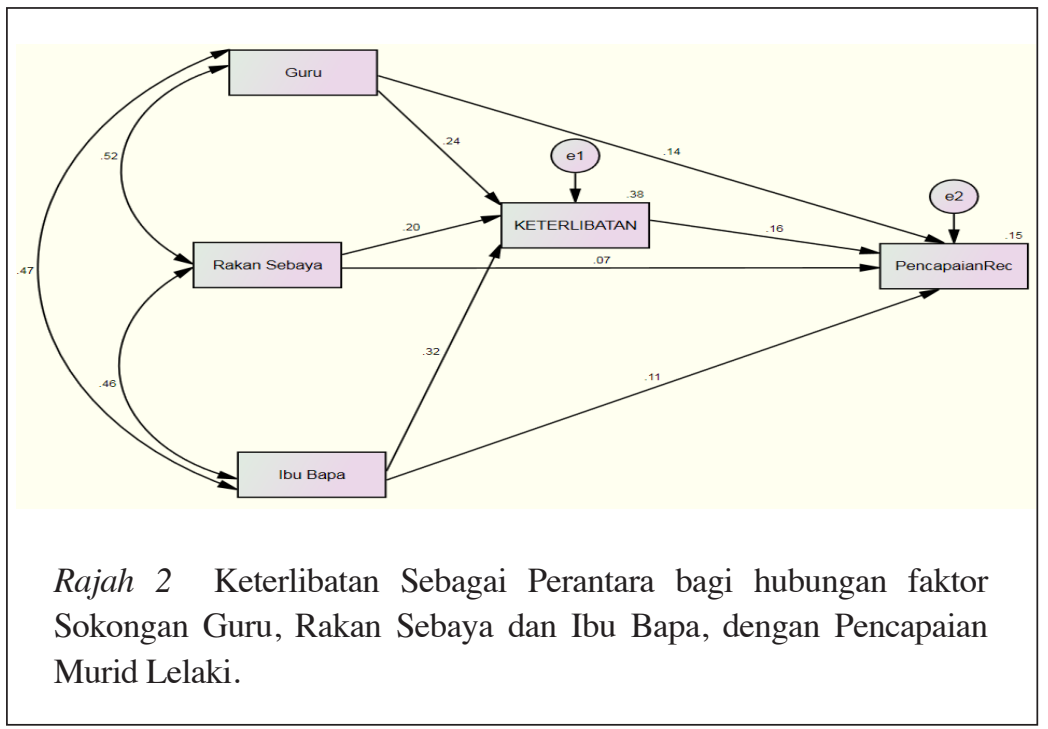

Rajah 2 menunjukkan sumbangan keterlibatan sebagai perantara sokongan guru, rakan sebaya dan ibu bapa terhadap pencapaian akademik murid lelaki. Secara keseluruhannya, keputusan analisis laluan model persamaan struktur (SEM) menggunakan AMOS menunjukkan bahawa sokongan guru, sokongan rakan sebaya dan sokongan ibu bapa memberi kesan tidak langsung yang positif kepada pencapaian akademik melalui keterlibatan di sekolah $(\beta=0.16$, $\mathrm{p}<0.05)$. Ini membuktikan bahawa secara tidak langsung dan ditahap signifikan, keterlibatan merupakan perantara bagi hubungan faktor sokongan guru, sokongan rakan sebaya dan sokongan ibu bapa, dengan pencapaian akademik murid lelaki. Dapatan ini memberi maksud bahawa keterlibatan memainkan peranan sebagai perantara 
bagi hubungan antara faktor pembelajaran terhadap pencapaian murid lelaki. Manakala secara langsung pula, sokongan guru menunjukkan kesan yang paling tinggi terhadap keterlibatan di sekolah $(\beta=0.14$, $\mathrm{p}<0.05)$ dan sokongan ibu bapa $(\beta=0.11, \mathrm{p}<0.05)$. Keputusan ini membuktikan bahawa sokongan guru dan ibu bapa merupakan pemboleh ubah peramal yang signifikan terhadap pencapaian.

ii. Keterlibatan sebagai perantara sumbangan sokongan guru, rakan sebaya dan ibu bapa terhadap pencapaian murid perempuan

Untuk menguji sama ada keterlibatan murid di sekolah sebagai perantara bagi hubungan faktor sokongan guru, rakan sebaya dan ibu bapa dengan pencapaian akademik murid perempuan, analisis perantaraan menggunakan SEM telah dijalankan. Keputusan analisis laluan model persamaan SEM menggunakan AMOS menunjukkan ukuran Chi Square/ $\mathrm{df}=3.68$, Root Mean Square Error Approximation (RMSEA) $=0.03$, Goodness of Fit Index $(G F I)=0.92$ dan Comparative Fit Index $(C F I)=0.91$. Kesemua jenis ukuran penilaian yang digunakan juga menunjukkan bahawa data yang digunakan dalam kajian ini terbukti mempunyai penyesuaian munasabah bagi model yang dicadangkan (Byrne, 2010).

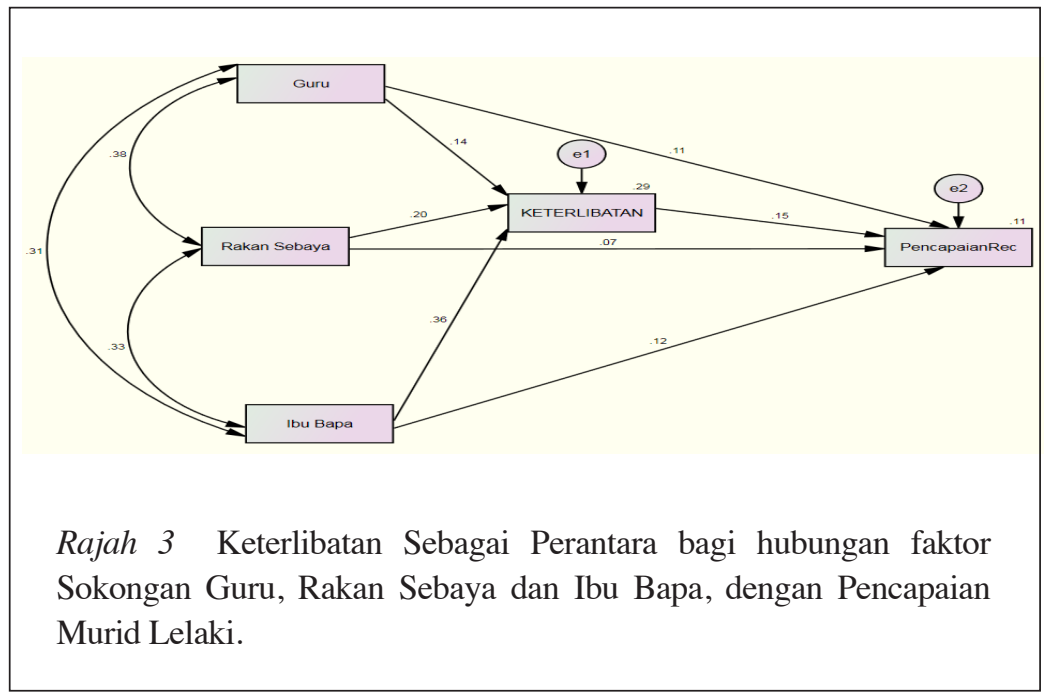

Rajah 3 menunjukkan peranan keterlibatan sebagai perantara sokongan guru, sokongan rakan sebaya dan sokongan ibu bapa terhadap pencapaian bagi murid perempuan. Berdasarkan rajah 
3, secara keseluruhannya, keputusan analisis laluan model persamaan struktur (SEM) menggunakan AMOS menunjukkan bahawa secara tidak langsung, sokongan guru, sokongan rakan sebaya dan sokongan ibu bapa memberi kesan tidak langsung yang positif kepada pencapaian akademik melalui keterlibatan di sekolah $(\beta=0.15, \mathrm{p}<0.05)$. Ini membuktikan bahawa secara tidak langsung dan di tahap signifikan, keterlibatan merupakan perantara bagi hubungan faktor sokongan guru, sokongan rakan sebaya dan sokongan ibu bapa, dengan pencapaian akademik murid perempuan. Manakala secara langsung pula, sokongan ibu bapa menunjukkan kesan yang paling tinggi terhadap keterlibatan di sekolah $(\beta=0.12$, $\mathrm{p}<0.05)$ di ikuti dengan sokongan guru $(\beta=0.11, \mathrm{p}<0.05)$. Keputusan ini membuktikan bahawa sokongan ibu bapa dan guru merupakan pemboleh ubah peramal yang signifikan terhadap pencapaian. Dapatan ini memberi maksud bahawa keterlibatan memainkan peranan sebagai perantara bagi hubungan antara faktor pembelajaran terhadap pencapaian murid perempuan.

\section{KESIMPULAN}

Berdasarkan dua objektif kajian ini, analisis data menunjukkan dapatan berikut. Pertama, hubungan keterlibatan murid dan sokongan pembelajaran dengan pencapaian menunjukkan min keterlibatan murid perempuan di sekolah dan pencapaian akademik adalah lebih baik berbanding murid lelaki. Dapatan kajian juga menunjukkan min sokongan pembelajaran dan pencapaian akademik yang lebih baik bagi murid perempuan berbanding lelaki. Hal ini bermakna murid perempuan mempunyai persepsi yang lebih tinggi terhadap keterlibatan dan sokongan pembelajaran walaupun kesan saiz perbezaan tersebut adalah kecil.

Bagi objektif kedua, hasil analisis SEM menunjukkan bahawa terdapat kesepadanan yang baik antara model dengan data dalam sampel kajian. Bagi murid lelaki, sokongan guru menunjukkan kesan langsung paling tinggi terhadap keterlibatan murid di sekolah, diikuti oleh sokongan ibu bapa. Sokongan guru, rakan sebaya dan ibu bapa memberi kesan tidak langsung yang positif kepada pencapaian akademik melalui keterlibatan di sekolah. Manakala bagi murid perempuan pula, sokongan ibu bapa menunjukkan kesan yang paling tinggi terhadap keterlibatan mereka di sekolah, diikuti sokongan guru. Secara tidak langsung, keterlibatan merupakan 
perantara sokongan guru, rakan sebaya dan ibu bapa terhadap pencapaian akademik murid perempuan.

Dapatan kajian seterusnya mendapati sokongan pembelajaran guru, rakan sebaya dan ibu bapa merupakan faktor yang memberikan sumbangan tidak langsung melalui keterlibatan kepada pencapaian murid. Ini bermakna sokongan guru, rakan sebaya dan ibu bapa adalah penggalak utama keterlibatan murid di sekolah terhadap pencapaian akademik murid. Dapatan ini selari dengan dapatan kajian Willms (2003); Fredricks et al. (2005); Lam et al. (2012) bahawa ibu bapa, guru dan rakan sebaya merupakan pendorong kepada keterlibatan murid di sekolah. Dapatan kajian ini juga menyokong hasil kajian Mohd Jelas et al. (2014); Chohan dan Khan (2010); Chen (2008) yang membuktikan bahawa keterlibatan murid di sekolah adalah perantara hubungan antara sokongan guru, ibu bapa dan rakan dengan pencapaian akademik. Hal ini menunjukkan bahawa hubungan guru dan rakan sebaya yang positif memainkan peranan penting dalam menggalakkan keterlibatan murid untuk terus berusaha dan mencapai kejayaan. Begitu juga halnya hubungan ibu bapa dengan murid yang sentiasa memberikan galakan membina untuk terus berusaha dalam meningatkan pencapaian akademik mereka.

Sokongan pembelajaran terbukti membantu murid dalam meningkatkan pencapaian akademik selain merupakan penyumbang kepada keterlibatan murid di sekolah. Penemuan ini menyokong dapatan kajian Mohd Jelas, Salleh, Azman, Hamzah, Jani, Hamzah, Ab Hamid. \& Mahmud (2013); Syed Sahil \& Awang-Hashim (2011) yang mendapati peningkatan keterlibatan murid di sekolah dapat meningkatkan pencapaian murid. Walau bagaimanapun, dapatan kajian ini didapati tidak selari dengan kajian Lam et al. (2012) bahawa terdapat perbezaan gender dalam hubungannya dengan keterlibatan murid dan pencapaian. Ketidakselarian dapatan kajian ini dengan kajian Lam et al. (2012) mungkin disebabkan oleh perbezaan latar belakang dan lokasi murid. Kajian ini hanya berdasarkan latar belakang dan lokasi murid dalam daerah Kuala Selangor. Kajian akan datang perlu meluaskan lagi lokasi dan latar belakang murid ke seluruh negara.

Hasil kajian ini juga mendapati bahawa sokongan guru menunjukkan kesan secara langsung paling tinggi diikuti oleh sokongan ibu bapa terhadap pencapaian murid lelaki. Bagi murid perempuan pula, kesan secara langsung paling tinggi adalah sokongan ibu bapa dan diikuti 
oleh sokongan guru. Namun, sokongan rakan sebaya tidak memberi kesan langsung kepada pencapaian bagi kedua-dua gender. Hal ini bermaksud rakan sebaya kurang menyumbang kepada pencapaian murid bagi kedua-dua gender. Dapatan ini tidak selari dengan dapatan Lam et al. (2012) dan Wang \& Holcombe (2010) bahawa sokongan rakan sebaya terhadap pencapaian adalah lemah bagi murid lelaki tetapi kukuh bagi murid perempuan. Dapatan kajian ini juga tidak selari dengan hasil kajian Mohd Jelas et al. (2014) yang mendapati sokongan pembelajaran rakan sebaya merupakan faktor yang memberikan sumbangan langsung kepada pencapaian murid sementara sokongan guru serta ibu bapa tidak memberi sumbangan langsung terhadap pencapaian akademik. Dapatan yang tidak signifikan bagi sokongan rakan sebaya terhadap pencapaian murid ini adalah berkemungkinan kerana, pada peringkat remaja, secara umumnya, rakan sebaya lebih memberikan galakan untuk bersosial sahaja manakala ibu bapa dan guru sentiasa memberikan galakan untuk terus berusaha bagi meningkatkan pencapaian akademik.

Walaupun dapatan kajian ini menunjukkan bahawa kesan secara langsung sokongan rakan sebaya tidak memberi sumbangan terhadap pencapaian akademik murid kepada kedua-dua gender, namun, kesan secara tidak langsung melalui perantara keterlibatan murid menunjukkan bahawa sokongan rakan sebaya memberi kesan terhadap keterlibatan murid, dan seterusnya pencapaian murid bagi kedua-dua gender. Justeru, dapatan ini mengukuhkan dapatan hasil kajian Mohd Jelas et al. (2014) iaitu keterlibatan murid adalah perantara sokongan pembelajaran terhadap pencapaian bagi keduadua gender. Dapatan kajian ini mengukuhkan lagi dapatan kajian Chen (2008), Simons-Morton \& Chen (2009) dan Lam et al. (2012) yang menunjukkan bahawa sokongan pembelajaran guru, rakan sebaya dan ibu bapa memberi kesan langsung kepada keterlibatan murid terhadap pencapaian.

\section{RUMUSAN DAN IMPLIKASI}

Dapatan kajian ini telah menyumbang untuk meningkatkan kefahaman dan ilmu sedia ada tentang faktor yang mempengaruhi pencapaian akademik murid. Secara ringkasnya, keseluruhan hasil kajian merumuskan bahawa sokongan pembelajaran melalui keterlibatan murid di sekolah sebagai perantara, akan menyumbang kepada pencapaian murid lelaki dan perempuan. Hasil kajian juga 
menunjukkan bahawa keterlibatan murid di sekolah adalah hasil daripada peranan dan sokongan daripada guru, rakan sebaya dan ibu bapa, dan seterusnya mempengaruhi peningkatan pencapaian akademik bagi kedua-dua gender. Jelas bahawa guru memainkan peranan penting dalam menggalakkan murid untuk meningkatkan pencapaian mereka. Remaja yang merasakan mereka dihargai guru menunjukkan keterlibatan emosi dan tingkah laku positif di sekolah. Kajian ini memberi implikasi untuk guru mencari pendekatan yang sesuai yang dapat menggalakkan murid untuk bersaing secara sihat sesama mereka, seterusnya menggalakkan keterlibatan murid dalam aktiviti di sekolah. Semakin tinggi keterlibatan murid di sekolah, semakin meningkat pencapaian mereka dalam pencapaian akademik.

Pihak pengurusan sekolah di peringkat daerah (PPD) perlu merancang untuk membentuk modul pembelajaran dan pemudahcaraan (PdPc). Kursus dan bengkel pengajaran kepada guru adalah perlu bagi mengukuhkan kemahiran PdPc. Latihan guru yang berterusan adalah penting untuk menggalakkan guru menggunakan kaedah yang bersesuaian dengan persekitaran sekolah (Furrer \& Skinner, 2003; Roorda, Koomen, Spilt \& Oort, 2011). Dalam hal ini, pihak sekolah boleh melaksanakan program latihan tambahan kepada Guru Bimbingan dan Kaunseling dalam aspek perkembangan dan pembangunan pelajar khususnya dalam meningkatkan keterlibatan murid di sekolah.

Implikasi kajian ini juga menggalakkan pihak sekolah untuk menyakinkan ibu bapa untuk melibatkan diri dalam aktiviti murid di sekolah. Program sarana ibu bapa yang dilaksanakan di sekolah perlu diteruskan dan ditambah baik dari masa ke semasa. Hubungan erat ibu bapa dengan murid adalah penting untuk peningkatan pencapaian akademik murid. Hubungan antara ibu bapa dan murid dapat meningkatkan pencapaian murid (Chen, 2008). Ibu bapa seharusnya memberi tumpuan yang lebih dan mengambil berat terhadap anak mereka serta membantu mereka dalam pembelajaran di sekolah dan luar sekolah. Ibu bapa yang menyediakan sokongan akademik, seperti bantuan dalam kerja sekolah di rumah, dan sokongan motivasi, seperti berbincang mengenai sekolah dan memantau kegiatan anakanak, akan menyumbang kepada pencapaian akademik anak mereka (Mohd Jelas et al., 2014). Penglibatan ibu bapa secara langsung dalam pelajaran anak-anak dapat meningkatkan tahap keterlibatan mereka di sekolah (Mohd Jelas et al., 2014; Lam et al., 2012). 
Ini secara langsung akan meningkatkan lagi motivasi murid untuk terus berusaha dan berjaya. Justeru, ibu bapa perlu diberi maklumat berkaitan kemahiran asuhan berkesan serta maklumat pendidikan lanjutan dan kerjaya murid. Ibu bapa perlu dibekalkan dengan senarai semak kandungan perbincangan dengan anak-anak tentang mata pelajaran yang anak kurang berminat, aspirasi dan keputusan yang dipersetujui bersama anak tentang tindakan yang akan diambil. Ibu bapa perlu berbincang bersama anak tentang tahap kemajuan dari masa ke semasa, memantau anak-anak menyiapkan tugasan sekolah di rumah di samping menyediakan keperluan pembelajaran dalam lingkungan kemampuan keluarga.

Tidak dapat dinafikan bahawa rakan sebaya merupakan agen sosialisasi penting murid terutama di peringkat remaja. Sokongan rakan sebaya adalah peramal kuat prestasi akademik murid (Mohd Jelas et al., 2016). Hubungan yang baik dengan rakan sebaya dapat menggalakkan murid untuk bersama menghadirkan diri dalam aktiviti di sekolah. Pembelajaran secara koperatif yang memerlukan murid untuk berbincang dan bekerjasama dalam kumpulan akan mengeratkan hubungan murid dengan rakan sebaya (Ormrod, 2006). Hal ini akan menggalakkan lagi keterlibatan murid dalam sekolah dan seterusnya meningkatkan pencapaian murid di sekolah. Oleh itu, Program Pembimbing Rakan Sebaya di sekolah perlu diperluaskan pelaksanaannya dan penubuhan kumpulan rakan sebaya di bawah seliaan guru mata pelajaran perlu juga diperbanyakkan di setiap kelas. Kumpulan rakan sebaya akan terlibat dengan aktiviti perbincangan berkumpulan, menyiapkan tugasan sekolah secara berkumpulan serta melaksanakan aktiviti pembelajaran mengikut minat mereka dengan bimbingan dan pemantauan guru dari masa ke semasa. Selain itu, penilaian keberkesanan program rakan sebaya ke atas keterlibatan murid juga perlu dilakukan pada penghujung tahun persekolahan.

Terdapat beberapa batasan dalam kajian ini. Data kajian dikutip secara keratan rentas dan dianalisis berdasarkan korelasi antara pemboleh ubah yang diukur. Kajian ini hanya mengkaji keterlibatan murid yang hanya memfokuskan murid tingkatan empat di sekolah menengah kebangsaan bercampur gender. Cadangan kajian lanjutan perlu memperinci dan memperluaskan lagi lingkungan umur responden dengan meninjau perbezaan dua kumpulan responden berdasarkan pemboleh ubah demografi seperti latar belakang keluarga, sosio ekonomi keluarga dan lokasi sekolah luar bandar 
dan bandar. Maklumat yang diperolehi akan menyediakan garis panduan untuk tindakan selanjutnya bagi mengurangkan jurang dalam pencapaian akedemik murid lelaki dan perempuan.

Sebagai negara yang menuju ke arah negara maju, keperluan untuk terus meningkatkan tahap pendidikan amatlah diperlukan selaras dengan teras pembelajaran abad ke 21 yang menekankan 11 anjakan untuk transformasi sistem pendidikan di bawah Pembangunan Pendidikan Malaysia 2013-2025. Justeru, dapatan kajian ini dapat memberi sumbangan kepada pengurusan sekolah dalam meningkatkan pencapaian akademik dan mengurangkan jurang perbezaan antara gender. Ia juga menjadi sumber maklumat kepada pihak pengurusan sekolah untuk menyusun strategi yang lebih baik untuk meningkatkan keterlibatan murid dengan sistem sokongan pembelajaran yang lebih mantap dan berkesan. Hasil kajian ini juga memberi input yang berguna kepada Kementerian Pendidikan Malaysia (KPM) dan Kementerian Pengajian Tinggi (KPT) untuk mengenal pasti peranan sokongan pembelajaran dalam keterlibatan murid terhadap pencapaian berdasarkan gender.

\section{RUJUKAN}

Ahmad, N. (2000). Kaunseling Remaja. Kuala Lumpur: Utusan Publications \& Distributors.

Ahmad, N. A., Mohd Jelas, Z. \& Mohd Ali, M. (2011). The relationship between learning styles and strategies with academic achievement based on gender and type of school. Malaysia International Journal of Learning, 17, 265-278.

Arbaa, R., Jamil,H., \& Abd Razak, N. (2010). Hubungan guru-pelajar dan kaitannya dengan komitmen belajar pelajar: Adakah guru berkualiti menghasilkan perbezaan pembelajaran antara jantina pelajar? Jurnal Pendidikan Malaysia, 35 (2), 61-69.

Awang-Hashim, R., Hashim, J., Yaakub, N. F., Othman, A. H., \& Md Ali, R. (2004). Correlates of avoidance help-seeking behaviours among Malaysian adolescents. Malaysian Journal of Learning \& Instruction, 1 (1), 31-50.

Bandura, A. (1989). Social cognitive theory. In R. Vasta (Ed.), Annals of child development: Vol. 6. Six theories of child development (pp. 1-60). Greenwich, CT: JAI.

Bempechat, J. \& Shernoff, D. J. (2012). Parential influences on achievement motivation and student engagement. In L. Sandy Christenson, Amy L. Reschly \& Cathy Wylie (Eds.), 
Handbook of research on student engagement, (pp. 315-342). New York: Springer.

Brook, R., Brooks, S. \& Goldstein, S. (2012). The power of mindsets:

Nurturing engagement, motivation, and resilience in student.

In L. Sandy Christenson, Amy L. Reschly \& Cathy Wylie (Eds.), Handbook of research on student engagement, (pp. 541-562). New York: Springer.

Byrne, B. M. (2010). Structural equation modelling with AMOS:

Basic concepts, applications and programming. New York: Routledge.

Chen, J. J.-L. (2008). Grade-level differences: Relations of parental, teacher and peer support to academic engagement and achievement among Hong Kong students. School Psychology International, 29 (2), 183-198.

Chohan, B. I., \& Khan, R. M., (2010). Impact of parental support on the academic performance and self concept of the student. Journal of Research and reflections in Education. 4,14-26. Retrieved from http://ue.edu.pk/jrre/articles/41002.pdf.

Croninger, R. G., \& Lee, V. E. (2001). Social capital and dropping out of high school: Benefits to at-risk students of teachers support and guidance. Teacher College Record, 103(4), 548581.

DiPerna, J. C., Volpe, R. J., \& Elliot, S. N. (2002). A model of academic enablers and elementary reading/language arts achievement. School Psychology Review, 31, 298-312.

Eccles, J. S \& Barber, B. L. (1999). Student council, volunteering, basketball or marching band: What kind of extracurricular involvement matters?. Journal Of Adolescent Research, 14(1), 10-43.

Epstein, D., Elwood, J., Jey, V. \& Maw, J. (1998). Failing boys: Issues in gender and achievement. Buckingham, PA: Open University Press.

Jaafar, F. M., Hashim, R. A., \& Ariffin, T. F. T. (2012). Malaysian University Student Learning Involvement Scale (MUSLIS): Validation of a Student Engagement Model. Malaysian Journal of Learning and Instruction, 9, 15-30.

Fredricks, J. A., Blumenfeld, P.C., \& Paris A. H. (2004). School engagement: Potential of the concept, state of the evidence. Review of Educational Research, 74, 59-109.

Fredricks, J. A., Blumenfeld, P., \& Friedel, J. (2005). What do children need to flourish? Conceptualizing and measuring indicators of positive development. In Moore K. A., Lippman 
L. H. (Eds.), School Engagement (pp. 305-321). New York: Springer.

Furlong, M. J., \& Christenson, S. L. (2008). Engaging students at school and with learning: A relevant construct for all students. Psychology in the Schools, 45, 365-368.

Furrer, C. \& Skinner, E. (2003). Sense of relatedness as a factor in children's academic engagement and performance. Journal of Educational Psychology, 95, 148-162.

Joseph, F. H., Earl, B., \& Frued, H. (1997). Explaining social issues. London: Pine Forge Press.

Jozefowicz, D. M, Colarossi, L., Arbreton, A.J, Eccles, J. S., \& Barber, B.L. (2000). Junior high school predictors of high school dropout, movement into alternative educational settings, and high school graduation: Implications for dropout prevention. School Social Work Journal, 25(1), 31-44.

Kementerian Pendidikan Malaysia. (2013). Laporan Tahunan 2017. Pelan Pembangunan Pendidikan Malaysia 2013-2025. Dicapai daripada https://www.padu.edu.my/

Kuh, K., Kinzie, J., Buckley, J., \& Bridges, B. Hayek.(2007). Piecing together the student success puzzle: Research, propositions, and recommendations. ASHE Higher Education Report, 32(5), 1-182.

Lam, S. F., Jimerson, S., Kikas, E. Cefai, C., Verga, F. H., Nelson, B., Hatzichristou, C., Polychroni, F., Basnett, J., Duck, R., Farrell, P., Liu, Y., Negovan, V., Shin, H., Stanculescu, E., Wong, B. P. H., Yang, H. \& Zollneritsch, J. (2012). Do girls and boys perceive themselves as equally engaged in school? The result of an international study from 12 countries. Journal of School Psychology, 50(1), 77-94.

Lam, S. F., Jimerson, S., Basnett, J., Cefai, C., Duck, R., \& Farrell, P. (2009, July). Exploring student engagement in schools internationally: A collaborative international study yields further insights. In A symposium at the 31st annual international school psychology association colloquium, Malta.

Mahatmya, D., Lohman, B. J., Matjasco, J. L. \& Farb, A.F. (2012). Engagement across developmental periods. In L. Sandy Christenson, Amy L. Reschly \& Cathy Wylie (Eds.), Handbook of research on student engagement, (pp. 45-64). New York: Springer.

Md Jaafar, F., Awang-Hashim, R., \& Tengku Ariffin,T.F (2012). Malaysian University Student Learning Involvement Scale (MUSLIS): Validation of a student engagement 
model. Malaysian Journal of Learning and Instruction (MJLI), 9, 15-30.

Mearns, K., Meyer, J., \& Bharadwaj, A. (2007). Student engagement in human biology practical sessions. Refereed paper presented at the Teaching and Learning Forum 2007, Curtin University of Technology, January 30-31. Perth, Australia.

Mohd Jelas, Z., Mohd Yunus, K. R., Mohd Dahan, H., \& Redzuan, M. (2001). Kajian pencapaian akademik pelajar lelaki dan perempuan. Laporan yang diserahkan ke Jabatan Pengajian Tinggi, Kementerian Pendidikan Malaysia. UKM: UKM Pakarunding.

Mohd Jelas, Z., Rahman, S., Baki, R., \& Ahmad, J. (2005). Prestasi akademik mengikut gender. Jurnal Pendidikan, 30, 93-111.

Mohd Jelas, Z., Salleh, A., Azman, N., Hamzah, R., Jani, R., Hamzah, H., Ab Hamid. Z., \& Mahmud, I.(2013). Analisis gender dalam pendidikan. Laporan Akhir Kajian Mei 2013. Universiti Kebangsaan Malaysia, Bangi. KPT.R.620-1/1/3 Jld.32 [17].

Mohd Jelas,Z., Salleh, A.,Azman, N., Jani, R.,Hamzah, R., Mahmud, I., Ab Hamid, Z., Hamzah., H \& Zulnaidi, H. (2014). Gender differences in learning support and academic achievement: The mediating role of student engagement. Malaysian Journal of Learning and Instruction,11(1), 237-262.

Mohd Jelas, Z., Azman, N., Zulnaidi, H., Ahmad,. N. A. (2016). Learning support and academic achievement among Malaysian adolescents: The mediating role of student engagement. Learning Environments Research, 19(2), 221-240.

doi: 10.1007/s10984-015-9202-5.

Ormrod J.E. 2006. Educational Psychology: Developing Learners 5th Ed. Pearson Educational International: Upper Saddle River, New Jersey.

Pallant, J. 2005. SPSS survival manual: A step guide to data analysis using SPSS for window (version 12). 2nd Ed. Maidenhead: Open University Press.

Pianta, R. C., Hamre, B. K. \& Allen, J. P. (2012). Teacher-student relationships and engagement: Conceptualising, measuring and improving the capacity of classroom interactions. In L. Sandy Christenson, Amy L. Reschly \& Cathy Wylie (Eds.), Handbook of research on student engagement, (pp. 365-386). New York: Springer.

Rumberger, R. W., \& Lim, S. A. (2008). Why students drop out of school: A review of 25 years of research. California Dropout Research Project, 15, 1-3. Retrieved from http://www.issuelab. org/resources/11658/11658.pdf 
Rumberger, R. (2011). Dropping Out: why students drop out of high school and what can be done. Harvard University Press.

Rodriguez, T. D. (2003). SchoolSocial Context Effects on Gender Differences in Academic Achievement Among SecondGeneration Latinos. Journal of Hispanic Higher Education, 2, 30-45.

Roorda, D. L., Koomen, H. M. Y., Spilt, J. L., \& Oort, F. J. (2011). The influence of affective teacher-student relationships on students' school engagement and achievement: A metaanalytic approach. Review of Educational Research, 81, 493529.

Simons-Morton, B., \& Chen, R. (2009). Peer and parent influences on school engagement among early adolescents. Youth \& Society Journal, 4l(1), 3-25.

Skinner, E. A. \& Pitzer, J. R. (2012). Developmental Dynamics of Student Engagement, Coping, and Everyday Resilience. In L. Sandy Christenson, Amy L. Reschly \& Cathy Wylie (Eds), Handbook of Research on Student Engagement (pp. 21 - 44). New York: Springer.

Skinner, E. A., \& Belmont, M. J. (1993). Motivation in the classroom: Reciprocal effects of teacher behavior and student engagement across the school year. Journal of Educational Psychology, 85, 571-581.

Syed Sahil, S. A., \& Awang Hashim, R. (2011). The role of social support in promoting Adolescents' classroom cognitive engagement through academic self efficacy. Malaysian Journal of Learning \& Instruction, 8, 49-69.

Trowler, V. (2010). Student engagement literature review. Higher Education, (November), 1-15. Retrieved from http:// americandemocracy.illinoisstate.edu/documents/democratic engagement-white-paper-2_13_09.pdf.

Vasalampi, K., Salmela-Aro, K., \& Nurmi, J.-E. (2009). Adolescents' self-concordance, school engagement, and burnout predict their educational trajectories. European Psychologist, 14(4), 332-341.

Veronneau, M. H. \& Dishion,T. J. (2011). Middle school friendships and academic achievement in early adolescence: Alongitudinal analysis. Journal of Early Adolescence, 31(1), 99 - 124.

Walberg, H. J. (1981). A psychological theory of educational productivity. In F.H.Farley \& N. Gordon (Eds.), Psychological and Education (pp.81-110). Chicago: National Society for the Study of Education. 
Wang, M. T., \& Holcombe, R. (2010). Adolescents' perception of school environment, engagement, and academic achievement in middle school. American Behavioural Research Journal, 47(3), 633-662.

Wang, M. T., \& Eccles, J. S. (2012). Social support matters: Longitudinal effects of social support on three dimensions of school engagement from middle to high school. Child Development, 83(3), 877-895.

Willms, J. D. (2003). Student engagement at school: A sense of belonging and participation. USA: Organisation For Economic Co-Operation And Development. Retrieved from http://www. oecd.org/education/school/programmeforinternationalstuden tassessmentpisa/33689437.pdf.

Welch, B. K., \& Bonnan-White, J. (2012). Twittering to increase student engagement in the university classroom. Knowledge Management and E-Learning, 4 (3), 325-345.

Wu, J. Y., Hughes, J. N., \& Kwok, O. M. (2010). Teacher-student relationship quality type in elementary grades: Effects on trajectories for achievement and engagement. Journal of school psychology, 48(5), 357-387. Retrieved from http:// www.ncbi.nlm.nih.gov/pmc/articles/PMC2928164/pdf/ nihms-193783.pdf

Yazzie-Mintz, E. (2009). Charting the path from engagement to achievement: Report on the 2009 high school survey of study engagement. Bloomington, IN: Center for Evaluation \& Education Policy. Retrieved from http://ceep.indiana.edu/ hssse/images/HSSSE_2010_Report.pdf.

https://www.mohe.gov.my/muat-turun/awam/statistik/2015/215bab-1-makro-institusi-pendidikan-tinggi-1

https://www.mohe.gov.my/muat-turun/awam/statistik/2016statistik/401-bab-1-makro-institusi-pendidikan-tinggi-2 